\title{
RESPON GENOTIPE KEDELAI BIJI BESAR DAN UMUR GENJAH TERHADAP KOMPLEKS HAMA PENGISAP POLONG
}

\author{
Marida Santi Yudha Ika Bayu, Ayda Krisnawati, \& M. Muchlish Adie \\ Balai Penelitian Tanaman Aneka Kacang dan Umbi \\ J1. Raya Kendalpayak KM. 8 PO BOX 66 Malang, Indonesia \\ E-mail: santi4_nov@yahoo.co.id
}

\begin{abstract}
Response of large seed size and early maturing soybean genotypes against pod sucking bugs complex. Pod sucking bugs (Hemiptera: Pentatomidae) is the most detrimental pest on soybean in Indonesia. These pest attacks caused the decreasing of quality and quantity of yield as well as decreased seed germination. The use of resistant varieties is an alternative control which is environmentally friendly. The objective of this study was to determine the response of various soybean genotypes against pod sucking complex in the field. The experiment was conducted on June to September 2015 in Pasuruan, East Java. The treatment was arranged in randomized block design, 16 treatments with three replicates. The treatment consists of 14 soybean promising lines (G $511 \mathrm{H} / \mathrm{Anj} / / \mathrm{Anj} / / / \mathrm{Anj}-11-2$, G $511 \mathrm{H} /$ Anjasmoro-1-6, G $511 \mathrm{H} /$ Anj//Anj///Anj-7-1, G 511 H/Anjasmoro/ /Anjasmoro-5-1, G 511 H/Argom//Argom-2-1, G 511 H/Anjasmoro-1-4, G 511 H/Anjasmoro-1-2, G 511 H/Anjasmoro//Anjasmoro2-8, G 511 H/Arg//Arg///Arg///Arg-12-15, G 511 H/Anj// Anj///Anj-6-3, G 511 H/Arg//Arg///Arg///Arg-19-7, G 511 H/Anjasmoro1-7, G $511 \mathrm{H} / \mathrm{Anj} / / \mathrm{Anj} / / /$ Anj////Anjs-6-7, G $511 \mathrm{H} /$ Anjasmoro-1-4-2), and two varieties (Anjasmoro and Grobogan). The results showed that the differences in soybean genotypes significantly influence the intensity of damaged pod and seed caused by pod sucking bugs. The intensity of damaged pod was $29.8-64.0 \%$ per plant. The intensity of damaged seed was $13.2-63.9 \%$ per plant. The number of puncture was 1.2-1.6 punctures per pod and 0.6-2.7 punctures per seed. Based on the intensity of damaged pod and seed, genotipe G 511 H/Anjasmoro//Anjasmoro-2-8, G 511 H/Anjasmoro-1-2, and G 511 H/Anjasmoro-1-6 were indicated consistently as moderately resistance against pod sucking complex. Those three genotypes could be use as a source of genes to improve the resistance of soybean against pod sucking bug.
\end{abstract}

Key words: damage intensity, morphological characters, pod sucking bug, soybean

\section{ABSTRAK}

Respon genotipe kedelai biji besar dan umur genjah terhadap kompleks hama pengisap polong. Pengisap polong merupakan hama yang berpotensi merugikan pada pertanaman kedelai di Indonesia. Serangan hama ini mengakibatkan penurunan kualitas dan kuantitas hasil panen, serta menurunnya daya kecambah biji. Penggunaan varietas tahan merupakan alternatif pengendalian yang ramah lingkungan. Tujuan penelitian ini adalah untuk mengetahui respon berbagai genotipe kedelai terhadap serangan kompleks pengisap polong di lapang. Penelitian dilaksanakan pada bulan Juni-September 2015 di Kabupaten Pasuruan, Jawa Timur. Rancangan percobaan yang digunakan adalah acak kelompok dengan 16 perlakuan dan diulang tiga kali. Perlakuan terdiri dari 14 galur harapan kedelai (G 511 H/Anj//Anj///Anj-11-2, G 511 H/Anjasmoro-1-6, G 511 H/Anj//Anj///Anj-7-1, G 511 H/Anjasmoro//Anjasmoro-5-1, G 511 H/Argom//Argom-2-1, G 511 H/Anjasmoro-1-4, G 511 H/Anjasmoro-1-2, G 511 H/ Anjasmoro//Anjasmoro-2-8, G $511 \mathrm{H} / \mathrm{Arg} / / \mathrm{Arg} / / / \mathrm{Arg} / / / \mathrm{Arg}-12-15, \mathrm{G} 511 \mathrm{H} / \mathrm{Anj} / / \mathrm{Anj} / / / \mathrm{Anj}-6-3, \mathrm{G} 511 \mathrm{H} / \mathrm{Arg} / / \mathrm{Arg} / / / \mathrm{Arg} / / /$ Arg-19-7, G 511 H/Anjasmoro-1-7, G 511 H/Anj//Anj///Anj////Anjs-6-7, G 511 H/Anjasmoro-1-4-2), dan dua varietas (Anjasmoro dan Grobogan). Hasil analisis ragam menunjukkan bahwa perbedaan genotipe kedelai berpengaruh signifikan terhadap intensitas serangan pengisap polong. Intensitas kerusakan polong akibat pengisap berkisar antara 29,8-64,0\% per tanaman. Intensitas kerusakan biji akibat pengisap berkisar antara 13,2-63,9\% per tanaman. Jumlah tusukan pengisap polong berkisar antara 1,2-1,6 buah per polong dan 0,6-2,7 buah per biji. Berdasarkan intensitas kerusakan polong dan biji, Genotipe G 511 H/Anjasmoro//Anjasmoro-2-8, G 511 H/Anjasmoro-1-2, dan G 511 H/Anjasmoro-1-6 terindikasi konsisten dengan kriteria agak tahan terhadap serangan pengisap polong. Ketiga genotipe tersebut dapat digunakan sebagai sumber gen untuk meningkatkan ketahanan varietas kedelai terhadap pengisap polong.

Kata kunci: intensitas kerusakan, karakter morfologi, kedelai, pengisap polong 


\section{PENDAHULUAN}

Pengisap polong (Hemiptera: Alydidae) merupakan hama polyphagus yang menyerang banyak jenis tanaman inang, diantaranya kelompok tanaman buah, tanaman dari famili Leguminoseae, dan tanaman serealia (Bae et al., 2009; Seo et al., 2011; Panizzi, 2013; Mainali et al., 2014). Pada tanaman kedelai, pengisap polong ini menyerang dengan cara menusuk dan mengisap bagian polong dan biji kedelai secara langsung dan tingkat serangannya tinggi pada fase pemasakan polong (Mainali \& Lim, 2012; Bae et al., 2014). Dampak yang ditimbulkan sangat serius yaitu berupa penurunan kualitas dan kuantitas hasil panen, serta menurunnya daya kecambah biji. Bae et al. (2014) melaporkan bahwa serangan pengisap polong Riptortus pedestris yang terjadi pada fase pengisian polong (R5) hingga panen dapat menyebabkan penurunan hasil hingga $70 \%$. Di Indonesia, spesies pengisap polong kedelai yang paling banyak ditemukan dan sangat merusak yaitu Riptortus linearis Fabricius, Nezara viridula Linnaeus, dan Piezodorus hybneri Gmelin (Bayu et al., 2011; Hendrival et al., 2013).

Imago pengisap polong adalah stadia yang paling merusak tanaman kedelai. Pengisap polong menyerang kedelai dengan cara menusukkan stiletnya pada polong dan mengisap cairan nutrisi yang terkandung pada biji. Serangan yang terjadi pada fase pembentukan polong akan menyebabkan polong kering dan gugur. Pada fase pertumbuhan polong dan perkembangan biji, pengisap polong menyebabkan polong dan biji kempis. Sedangkan, serangan yang terjadi pada fase pengisian biji atau pemasakan polong akan menimbulkan bercak hitam kecoklatan dan penampilan keriput pada biji. Menurut Depieri \& Panizzi (2011), waktu penyerangan pengisap polong berkorelasi positif dengan dampak yang ditimbulkan. Selain itu, meningkatnya pelukaan pada biji menyebabkan tertundanya umur masak tanaman (Leonard et al., 2011; Bae et al., 2014). Oleh karena itu, pengendalian pengisap polong sangat penting dilakukan hingga menjelang panen untuk mempertahankan hasil panen.

Insektisida kimia menjadi pilihan utama bagi petani kedelai pada umumnya untuk menyelamatkan pertanamannya dari serangan hama dan insektisida tersebut sering kali diaplikasikan secara berlebihan (Razaq et al., 2013; Panizzi, 2013). Meskipun telah diaplikasikan secara intensif, tingkat serangan pengisap polong pada kedelai sering masih tinggi, bahkan petani masih sering mengalami gagal panen. Aplikasi insektisida secara terus menerus dapat meningkatkan resistensi hama target dan membunuh serangga berguna (Cordeiro et al., 2014; Afifah et al., 2015; Haddi et al., 2015; Guedes et al., 2016).

Penanaman varietas tahan hama dalam rangka mengurangi penggunaan insektisida penting untuk dipertimbangkan. Penggunaan varietas tahan merupakan alternatif pengendalian yang ramah lingkungan (Smith \& Clement, 2012). Di Indonesia, beberapa genotipe kedelai, diantaranya IAC 100 dan $\mathrm{G} 100 \mathrm{H}$, dilaporkan tahan terhadap pengisap polong. Genotipe $\mathrm{G} 100 \mathrm{H}$ yang merupakan hasil persilangan antara varietas IAC 100 (introduksi dari Brazilia yang tahan pengisap polong) dengan Himeshirazu (introduksi dari Jepang, merupakan salah satu genotipe yang terindikasi tahan pengisap polong) (Bayu \& Tengkano, 2014). IAC 100 diketahui merupakan hasil persilangan antara varietas IAC-12 and IAC 78-2318, yang tahan terhadap serangga pemakan dan pengisap (Veiga et al., 1999). IAC 100 memiliki pertahanan yang kuat terhadap cekaman yang disebabkan oleh faktor biologi seperti pelukaan oleh hama (Timbo et al., 2014). IAC 100 juga terindikasi tahan terhadap pengisap polong (McPerson et al., 2007; Suharsono \& Sulistyowati, 2012; Bayu \& Tengkano, 2014). Selain itu, latar belakang genetik tanaman dan jenis penyebab cekaman mempengaruhi respon pertahanan tanaman terhadap suatu hama (Courtois et al., 2009). Berdasarkan hal-hal tersebut di atas, evaluasi terhadap genotipe kedelai terkait dengan ketahanannya terhadap pengisap polong sangat penting dilakukan. Tujuan penelitian ini adalah untuk mengetahui respon berbagai genotipe kedelai terhadap serangan kompleks pengisap polong di lapang.

\section{METODE PENELITIAN}

Tempat dan Waktu. Lokasi penelitian berada pada ketinggian $124 \mathrm{~m}$ di atas permukaan laut (dpl) dengan tipe tanah mediteran coklat dan tipe iklim E (agak kering) di Kabupaten Pasuruan, Jawa Timur. Penelitian dilaksanakan pada bulan Juni sampai September 2015.

Rancangan percobaan. Rancangan percobaan yang digunakan adalah acak kelompok dengan 16 perlakuan dan diulang tiga kali. Perlakuan terdiri dari 14 galur harapan kedelai (G $511 \mathrm{H} / \mathrm{Anj} / / \mathrm{Anj} / / / \mathrm{Anj}^{-11-2, ~ G ~} 511$ H/Anjasmoro-1-6, G 511 H/Anj//Anj///Anj-7-1, G 511 $\mathrm{H} /$ Anjasmoro//Anjasmoro-5-1, G $511 \mathrm{H} /$ Argom//Argom2-1, G 511 H/Anjasmoro-1-4, G 511 H/Anjasmoro-1-2, G 511 H/Anjasmoro//Anjasmoro-2-8, G 511 H/Arg//Arg/ //Arg///Arg-12-15, G 511 H/Anj// Anj///Anj-6-3, G 511 H/Arg//Arg///Arg///Arg-19-7, G 511 H/Anjasmoro-1-7, 
G 511 H/Anj//Anj///Anj///Anjs-6-7, G 511 H/Anjasmoro1-4-2) dan dua varietas yaitu Anjasmoro dan Grobogan.

Lokasi percobaan merupakan lahan sawah yang sebelumnya ditanami padi dan sebelum tanam kedelai tidak dilakukan pengolahan lahan. Saluran drainase dibuat sebelum tanam dan dilakukan aplikasi herbisida pada permukaan tanah. Ukuran plot percobaan adalah $2,4 \times 4,5 \mathrm{~m}$. Penanaman dilakukan dengan jarak tanam $40 \times 15 \mathrm{~cm}$, dua tanaman per rumpun. Pupuk yang digunakan adalah $250 \mathrm{~kg}$ Phonska ditambah $100 \mathrm{~kg}$ SP 36 dan satu ton pupuk organik per ha yang diberikan seluruhnya pada saat tanam. Perawatan benih (seed treatment) dilakukan dengan menggunakan insektisida berbahan aktif tiametoksam sesuai dosis yang direkomendasikan. Pengendalian gulma dilakukan pada tanaman umur 2 dan 4 minggu setelah tanam (MST). Pengendalian lalat kacang dilakukan dengan menggunakan insektisida berbahan aktif sipermetrin pada 8 hari setelah tanam (HST) dengan dosis $1 \mathrm{ml} / 1$, dilanjutkan dengan aplikasi insektisida berbahan aktif sihalotrin pada 14, 21, dan 28 HST untuk mengendalikan hama pemakan daun dengan dosis $2 \mathrm{ml} / \mathrm{l}$. Setelah tanaman berumur 28 hari, tidak dilakukan aplikasi insektisida dengan tujuan agar populasi pengisap polong datang ke pertanaman untuk menyerang.

Pengamatan. Pengamatan dilakukan terhadap banyaknya polong dan biji terserang pengisap polong pada saat panen. Pengambilan sampel dilakukan sebelum panen sebanyak 5 tanaman per plot secara acak. Pengamatan polong dan biji terserang dilakukan dengan menggunakan mikroskop binokuler di Laboratorium Entomologi Balai Penelitian Tanaman Aneka Kacang dan Umbi (Balitkabi). Penghitungan persentase intensitas polong dan biji terserang menggunakan rumus:

$$
\text { Polong terserang }=\frac{\text { Jumlah polong terserang }}{\text { Jumlah polong diamati }} \times 100 \%
$$$$
\text { Biji terserang }=\frac{\text { Jumlah biji terserang }}{\text { Jumlah biji diamati }} \times 100 \%
$$

Untuk menentukan tingkat ketahanan tanaman menggunakan metode seperti yang dilakukan oleh Asadi (2009) sebagai berikut:

Skor 1, serangan $0-20 \%=$ tahan

Skor 2, serangan $21-40 \%$ = agak tahan

Skor 3, serangan $41-60 \%=$ agak rentan

Skor 4 , serangan $61-80 \%=$ rentan

Skor 5 , serangan $>80 \%=$ sangat rentan
Tingkat serangan pengisap polong dianalisis menggunakan ANOVA (SPSS versi 22) dilanjutkan dengan uji beda nyata dengan Tukey pada taraf nyata $5 \%$.

\section{HASIL DAN PEMBAHASAN}

Intensitas polong dan biji terserang pengisap polong. Hasil analisis ragam menunjukkan bahwa perbedaan genotipe kedelai berpengaruh sangat nyata terhadap intensitas serangan pengisap polong pada polong dan biji kedelai $(\mathrm{p}<0.000)$ (Tabel 1). Intensitas serangan pengisap pada polong berkisar antara 29,8$64,0 \%$ per tanaman. Genotipe kedelai dengan intensitas polong terserang tertinggi adalah $\mathrm{G} 511 \mathrm{H} / \mathrm{Arg} / / \mathrm{Arg} / / /$ Arg///Arg-12-15 yaitu mencapai $64,0 \%$ per tanaman. Sedangkan, genotipe dengan intensitas polong terserang terendah adalah G $511 \mathrm{H} /$ Anjasmoro//Anjasmoro-2-8 yaitu $29,8 \%$ per tanaman.

Berdasarkan intensitas polong terserang yang dikelompokkan menggunakan kategori Asadi (2009), terdapat tiga genotipe kedelai yang terindikasi agak tahan terhadap serangan pengisap polong yaitu $\mathrm{G} 511 \mathrm{H} /$ Anjasmoro//Anjasmoro-2-8, G 511 H/Anjasmoro-1-6, dan G 511 H/Anjasmoro-1-2 dengan intensitas kerusakan polong berturut-turut $29,8 \%, 33,5 \%$, dan $40,1 \%$ per tanaman. Selain ketiga genotipe tersebut diatas, genotipegenotipe yang ditanam di Pasuruan pada MK 2 terindikasi agak rentan dan rentan terhadap pengisap polong.

Intensitas serangan pengisap polong pada biji dari 16 genotipe kedelai berkisar antara $13,2-63,9 \%$ per tanaman (Tabel 1). Intensitas serangan pengisap pada biji yang terendah terdapat pada varietas Grobogan, yaitu $13,2 \%$ per tanaman. Sedangkan, intensitas serangan pengisap pada biji yang tertinggi terdapat pada genotipe G $511 \mathrm{H} /$ Anj//Anj///Anj////Anjs-6-7 yaitu mencapai $63,9 \%$. Berdasarkan intensitas biji terserang, terdapat tiga genotipe kedelai yang terindikasi tahan terhadap serangan pengisap polong yaitu Grobogan, G $511 \mathrm{H} / \mathrm{Arg} /$ /Arg///Arg///Arg-19-7, dan G 511 H/Anjasmoro// Anjasmoro-2-8 dengan persentase biji terserang berturut-turut $13,2 \% ; 17,9 \%$; dan $19,2 \%$ per tanaman. Selain itu terdapat lima genotipe kedelai yang terindikasi agak tahan yaitu genotipe G $511 \mathrm{H} /$ Anjasmoro// Anjasmoro-5-1 (30\%/tanaman), G $511 \mathrm{H} /$ Anjasmoro1-2 (31,8\% per tanaman), G 511 H/Anjasmoro-1-6 (31,9\% per tanaman), G $511 \mathrm{H} / \mathrm{Anj} / / \mathrm{Anj} / / / \mathrm{Anj}-11-2$ (37,1\% per tanaman), dan Anjasmoro (39,4\% per tanaman).

Pada penelitian ini, intensitas serangan pengisap polong pada polong lebih tinggi bila dibandingkan dengan intensitas serangannya pada biji. Hasil penelitian ini 
Tabel 1. Tingkat serangan pengisap polong pada 16 genotipe kedelai di Kabupaten Pasuruan

\begin{tabular}{|c|c|c|c|c|}
\hline Genotipe & $\begin{array}{c}\text { Polong } \\
\text { terserang } \\
(\% / \text { tanaman })\end{array}$ & $\begin{array}{c}\text { Kriteria } \\
\text { ketahanan }\end{array}$ & $\begin{array}{l}\text { Biji terserang } \\
(\% / \text { tanaman })\end{array}$ & $\begin{array}{c}\text { Kriteria } \\
\text { ketahanan }\end{array}$ \\
\hline G 511 H/Anj//Anj///Anj-11-2 & $40,5 \mathrm{abc}$ & AR & 37,1 abcdef & AT \\
\hline G 511 H/Anjasmoro-1-6 & $33,5 \mathrm{bc}$ & AT & 31,9 bcdef & AT \\
\hline G 511 H/Anj//Anj///Anj-7-1 & $54,7 \mathrm{abc}$ & AR & $51,7 \mathrm{abc}$ & AR \\
\hline G 511 H/Anjasmoro//Anjasmoro-5-1 & $44,8 \mathrm{abc}$ & AR & 30,0 cdef & AT \\
\hline G 511 H/Argom//Argom-2-1 & $57,8 \mathrm{ab}$ & AR & $53,7 \mathrm{abc}$ & AR \\
\hline G 511 H/Anjasmoro-1-4 & $59,2 \mathrm{ab}$ & AR & $57,1 \mathrm{abc}$ & AR \\
\hline G 511 H/Anjasmoro-1-2 & $40,1 \mathrm{abc}$ & AT & 31,8 bcdef & AT \\
\hline G 511 H/Anjasmoro//Anjasmoro-2-8 & $29,8 \mathrm{c}$ & AT & 19,2 def & $\mathrm{T}$ \\
\hline G $511 \mathrm{H} / \mathrm{Arg} / / \operatorname{Arg} / / / \operatorname{Arg} / / / \operatorname{Arg}-12-15$ & $64,0 \mathrm{a}$ & $\mathrm{R}$ & $62,0 \mathrm{ab}$ & $\mathrm{R}$ \\
\hline G 511 H/Anj//Anj///Anj-6-3 & $52,5 \mathrm{abc}$ & AR & 48,1 abcde & AR \\
\hline G 511 H/Arg//Arg///Arg///Arg-19-7 & $46,4 \mathrm{abc}$ & AR & 17,9 ef & $\mathrm{T}$ \\
\hline G 511 H/Anjasmoro-1-7 & $58,6 \mathrm{ab}$ & AR & $52,6 \mathrm{abc}$ & AR \\
\hline G 511 H/Anj//Anj///Anj////Anjs-6-7 & $62,8 \mathrm{a}$ & $\mathrm{R}$ & $63,9 \mathrm{a}$ & $\mathrm{R}$ \\
\hline G 511 H/Anjasmoro-1-4 & $52,9 \mathrm{abc}$ & AR & 49,9 abcd & AR \\
\hline Anjasmoro & $44,8 \mathrm{abc}$ & AR & 39,4 abcdef & AT \\
\hline Grobogan & $62,0 \mathrm{a}$ & $\mathrm{R}$ & $13,2 \mathrm{f}$ & $\mathrm{T}$ \\
\hline $\mathrm{F}$ & 4,243 & & 7,034 & \\
\hline df & 15,32 & & 15,32 & \\
\hline $\mathrm{p}$ & $\mathrm{p}<0,000$ & & $\mathrm{p}<0,000$ & \\
\hline
\end{tabular}

Angka selajur yang diikuti oleh huruf yang sama menyatakan tidak berbeda nyata (Tukey's HSD test, $\mathrm{p}<0,05$ )

sejalan dengan hasil penelitian Asadi (2009), yaitu bahwa persentase polong terserang dari 17 genotipe yang diuji lebih tinggi bila dibandingkan dengan persentase biji terserang oleh pengisap polong. Alasan yang memungkinkan untuk menjelaskan fenomena ini adalah kekerasan kulit polong. Stilet pengisap diduga hanya mampu menjangkau kulit polong dan tidak mengenai permukaan biji karena kulit polong keras dan adanya rongga diantara kulit polong dengan biji. Suharsono \& Sulistyowati (2012) melaporkan bahwa ketebalan dan kekerasan kulit polong sangat nyata menurunkan tingkat serangan pengisap polong.

Perbedaan tingkat serangan pengisap pada polong dan biji beberapa genotipe kedelai pada penelitian ini juga diduga karena adanya keragaman stadia pengisap polong yang menyerang. Selain kepadatan populasi hama dan stadia pertumbuhan tanaman, keragaman tingat serangan pengisap polong dipengaruhi oleh stadia perkembangan hama (Lourencao et al., 2010; Depieri \& Panizzi, 2011). Menurut Arifin \& Tengkano (2010), tingkat kerusakan polong dan biji akibat serangan $P$. hybneri mulai terlihat oleh stadia nimfa instar 3, 4, dan 5 , serta imago pada 63 hari setelah tanam (HST). Depieri \& Panizzi (2011) juga melaporkan bahwa waktu penyerangan pengisap polong berkorelasi positif dengan dampak yang ditimbulkan. Nimfa $P$. hybneri instar 1 tidak bergerak dan nimfa instar 2 memiliki perilaku kurang gesit sehingga tingkat kerusakan yang ditimbulkan masih sangat rendah (Arifin \& Tengkano, 2010). Hal tersebut menguatkan dugaan bahwa nimfa hanya mampu mengisap kulit polong dan tidak melukai biji. Untuk dapat menyimpulkan secara lebih akurat, pengamatan populasi hama dan stadia yang menyerang perlu dilakukan pada penelitian berikutnya.

Penentuan tingkat ketahanan genotipe kedelai terhadap pengisap polong pada penelitian ini didasarkan pada kekonsistensian dari intensitas serangannya pada polong dan biji kedelai. Genotipe G $511 \mathrm{H} /$ Anjasmoro// Anjasmoro-2-8, G 511 H/Anjasmoro-1-2, dan G 511 H/ Anjasmoro-1-6 adalah genotipe-genotipe yang menunjukkan konsistensi dengan kategori agak tahan terhadap serangan pengisap polong berdasarkan polong 
dan biji terserang. Kekonsistensian kategori ketahanan berdasarkan polong dan biji terserang dinilai lebih kuat dalam pemilihan galur tahan terhadap serangan hama dibandingkan dengan pemilihan yang hanya didasarkan pada biji terserang saja. Biji terserang secara langsung lebih berpengaruh terhadap hasil, baik kualitas maupun kuantitas. Menurut Leonard et al. (2011), pelukaan pada biji akibat serangan hama menyebabkan umur masak tanaman menjadi tertunda. Namun, polong terserang yang ditandai dengan adanya bercak hitam pada kulit polong akan mempengaruhi ketertarikan konsumen dalam memilih kedelai segar.

Intensitas polong dan biji terserang pada genotipe G $511 \mathrm{H} /$ Anjasmoro//Anjasmoro-2-8, G $511 \mathrm{H} /$ Anjasmoro-1-2, dan G 511 H/Anjasmoro-1-6 lebih rendah dibandingkan dengan genotipe lainnya. Ketiga genotipe ini kurang terpilih oleh nimfa dan imago yang merupakan stadia pengisap polong yang paling merusak kedelai untuk mengisap cairan atau nutrisi yang terdapat pada polong dan biji kedelai tersebut. Sifat ketahanan yang dimiliki oleh ketiga genotipe tersebut adalah ketahanan antixenosis. Antixenosis adalah mekanisme ketahanan yang ditunjukkan oleh tanaman inang, yang menghalangi serangga untuk meletakkan telur, makan, mencari tempat berlindung, dan kolonisasi (Afzal et al., 2009; Morando et al., 2015). Ketahanan antixenosis tergolong sangat efektif karena dapat menyebabkan serangga kelaparan dan mati karena tidak mendapat sumber makanan.
Furstenberg-Hagg et al. (2013) dan War et al. (2012) melaporkan bahwa pertahanan tanaman terhadap serangan serangga herbivora terdiri dari pertahanan langsung yang meliputi trikoma (bulu pada tanaman), produksi metabolit primer (protein inhibitor dan enzim antioksidan), dan produksi metabolit sekunder (asam fenolik, flavonoid, dan isoflavon). Trikoma serta ketebalan kulit polong menjadi faktor penghalang utama bagi pengisap polong untuk menusukkan stiletnya (Souza et al., 2012). Selain itu, tanaman juga memiliki pertahanan tidak langsung melalui produksi senyawa organik yang mudah menguap seperti metil salisilat dan cis-jasmone yang dapat menarik musuh alami untuk datang sehingga serangga akan menjauhi tanaman tersebut (Courtois et al., 2009; Michereff et al., 2011; Colazza \& Wajnberg, 2013).

Pada Gambar 1 dapat dilihat adanya keeratan hubungan antara polong terserang dengan biji terserang pengisap polong dengan nilai $r=0,666$, artinya banyaknya polong yang terserang akan diikuti dengan banyaknya jumlah biji yang terserang. Namun, pada penelitian lapang ini, hubungan antara keduanya tidak begitu erat. Karakteristik polong memiliki peran penting dalam menghalangi kerusakan biji. Pada kasus yang demikian, stilet dari pengisap polong banyak yang hanya melukai kulit polong dan tidak menjangkau bagian biji.

\section{Jumlah tusukan pengisap polong pada polong dan}

biji. Hasil analisis ragam menunjukkan bahwa perbedaan genotipe kedelai tidak berpengaruh nyata

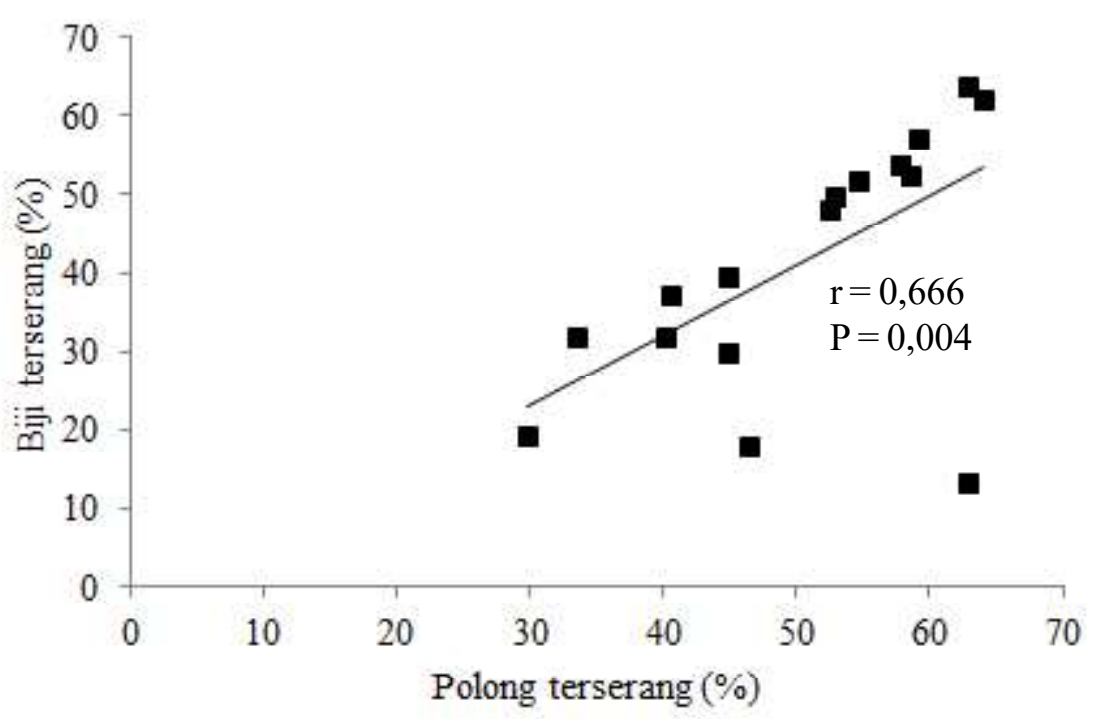

Gambar 1. Keeratan hubungan antara polong terserang (\%) dengan biji terserang (\%) pengisap polong pada 16 genotipe kedelai 
terhadap jumlah tusukan pengisap polong pada polong $(p<0,507)$ tetapi berbeda nyata terhadap jumlah tusukan pada biji $(\mathrm{p}<0,036)$. Jumlah tusukan pengisap polong berkisar antara 1,2-1,6 buah per polong dan $0,6-2,7$ buat per biji. Jumlah tusukan pada polong yang tertinggi terdapat pada varietas Grobogan (1,6 buah) dan yang terendah terdapat pada genotipe G $511 \mathrm{H} /$ Argom// Argom-2-1 dan G 511 H/Anjasmoro-1-4 masing-masing hanya 1,2 buah. Jumlah tusukan pada biji yang tertinggi terdapat pada genotipe G 511 H/Anjasmoro-1-6 dan G $511 \mathrm{H} /$ Anj//Anj///Anj////Anjs-6-7 yaitu masing-masing sebanyak 2,7 buah. Sedangkan jumlah tusukan pada biji yang terendah terdapat pada varietas Grobogan yaitu hanya 0,6 buah.

Varietas Anjasmoro dan Grobogan diketahui sebagai varietas yang banyak diminati oleh petani karena hasil panennya yang tinggi dan sesuai untuk bahan baku tahu dan tempe (Krisnawati et al., 2016). Berdasarkan pengelompokan kriteria ketahanan yang mengacu pada Asadi (2009), varietas Anjasmoro dan Grobogan menunjukkan ketidakkonsistenan kriteria ketahanan antara polong terserang dan biji terserang di lapang. Dilihat dari intensitas polong terserang, kedua varietas tersebut tergolong rentan. Sedangkan, berdasarkan intensitas biji terserang keduanya tergolong tahan terhadap pengisap polong. Pada varietas Grobogan, jumlah tusukan yang ditemukan pada polong tercatat paling banyak namun tusukan yang ditemukan pada biji tercatat paling sedikit. Hal ini terjadi karena stilet pengisap polong hanya melukai bagian permukaan polong varietas Grobogan dan banyak dari tusukan tersebut yang tidak mencapai permukaan biji. Bagi petani yang mengambil hasil biji, tentunya keadaan tingginya intensitas polong terserang ini bukan menjadi permasalahan jika didukung dengan intensitas kerusakan yang rendah pada biji. Meskipun demikian, penelitian lebih lanjut diperlukan untuk mengkonfirmasi hasil penelitian ini terutama pada kondisi dipaksakan atau pengujian dengan tanpa pilihan inang.
Pengisap polong merusak tanaman kedelai dengan cara menusuk dan mengisap polong serta biji kedelai. Polong dan biji yang terserang pengisap polong akan menunjukkan gejala berupa bercak atau titik hitam bekas tusukan stilet. Bercak hitam pada polong tersebut nampak jelas bila dilihat dari bagian permukaan dalam kulit polong. Serangan yang berat akan menyebabkan tusukan stilet pada polong dapat menembus hingga ke permukaan biji. Serangan terjadi pada saat pengisian biji, dapat menyebabkan biji tidak berkembang karena jaringan/sel yang mati berhenti berkembang.

Karakter Agronomi. Preferensi pengguna terhadap varietas kedelai masa kini, selain berdaya hasil tinggi, juga berumur masak genjah ( $<80$ hari), berukuran biji besar $(>14 \mathrm{~g} / 100$ biji) dan juga relatif toleran terhadap salah satu cekaman biotik maupun abiotik. Pengisap polong memiliki sebaran cukup luas di Indonesia dan menimbulkan kerusakan pada pertanaman kedelai pada berbagai musim tanam. Tersedianya varietas kedelai yang mampu memenuhi preferensi pengguna dan relatif tahan terhadap pengisap polong penting untuk pengembangan kedelai di daerah tropis Indonesia.

Sidik ragam terhadap umur masak, bobot 100 biji dan hasil biji dari 16 genotipe kedelai, diperoleh pengaruh perlakuan yang nyata untuk ketiga karakter (Tabel 2) menunjukkan terdapat perbedaan karakter agronomi dari 16 genotipe kedelai. Rentang umur masak adalah $75-$ 81 hari (rata-rata 76 hari), bobot 100 biji antara 15,22 $19,73 \mathrm{~g}$ (rata-rata $16,62 \mathrm{~g} / 100 \mathrm{biji}$ ) dan rentang hasil biji antara 2,01-2,55 ton/ha (rata-rata 2,30 ton/ha) (Tabel $3)$.

Genotipe yang menunjukkan konsisten agak tahan terhadap hama pengisap polong berdasarkan kerusakan pada polong maupun biji yaitu Genotipe G $511 \mathrm{H} /$ Anjasmoro//Anjasmoro-2-8, memiliki bobot 100 biji 16,87 $\mathrm{g}$ dengan potensi hasil 2,24 ton/ha dan umur masak 74 hari. Selain itu, terdapat genotipe G $511 \mathrm{H} /$ Anjasmoro1-2 memiliki umur masak 76 hari, bobot 100 biji 15,26 g

Tabel 2. Sidik ragam umur masak, bobot 100 biji dan hasil biji dari 16 genotipe kedelai. MK 2, 2015

\begin{tabular}{llll}
\hline & \multirow{2}{*}{ Karakter } & \multicolumn{2}{c}{ Kuadrat tengah } \\
\cline { 3 - 4 } & & Ulangan & Perlakuan \\
\hline Umur masak (hr) & $0,5208 \mathrm{tn}$ & $8,9958 * *$ \\
Bobot 100 biji $(\mathrm{g})$ & $6,2335 * *$ & $4,9187 * *$ \\
Hasil (t/ha) & $0,0237 \mathrm{tn}$ & $0,1691^{* *}$ \\
\hline
\end{tabular}

tn $=$ tidak nyata, $* *=$ nyata pada $\mathrm{p}=0,01$ 
Tabel 3. Karakter umur masak, bobot 100 biji dan hasil biji dari 16 genotipe kedelai. MK2, 2015

\begin{tabular}{clccc}
\hline No & \multicolumn{1}{c}{ Genotipe } & $\begin{array}{c}\text { Umur masak } \\
\text { (hari) }\end{array}$ & $\begin{array}{c}\text { Bobot 100 biji } \\
\text { (g) }\end{array}$ & $\begin{array}{c}\text { Hasil } \\
\text { (ton/ha) }\end{array}$ \\
\hline 1 & G 511 H/Anj//Anj///Anj-11-2 & 77 & 15,48 & 2,26 \\
2 & G 511 H/Anjasmoro-1-6 & 75 & 17,08 & 2,46 \\
3 & G 511 H/Anj//Anj///Anj-7-1 & 75 & 17,39 & 2,12 \\
4 & G 511 H/Anjasmoro//Anjasmoro-5-1 & 77 & 17,61 & 2,01 \\
5 & G 511 H/Argom//Argom-2-1 & 77 & 15,22 & 2,02 \\
6 & G 511 H/Anjasmoro-1-4 & 77 & 16,78 & 2,55 \\
7 & G 511 H/Anjasmoro-1-2 & 76 & 15,26 & 2,14 \\
8 & G 511 H/Anjasmoro//Anjasmoro-2-8 & 74 & 16,87 & 2,24 \\
9 & G 511 H/Arg//Arg///Arg///Arg-12-15 & 76 & 16,39 & 2,60 \\
10 & G 511 H/Anj//Anj///Anj-6-3 & 77 & 16,83 & 2,32 \\
11 & G 511 H/Arg//Arg///Arg///Arg-19-7 & 76 & 17,03 & 2,06 \\
12 & G 511 H/Anjasmoro-1-7 & 77 & 16,27 & 2,05 \\
13 & G 511 H/Anj//Anj///Anj///Anjs-6-7 & 77 & 16,48 & 2,03 \\
14 & G 511 H/Anjasmoro-1-4-2 & 77 & 15,93 & 2,44 \\
15 & Anjasmoro & 81 & 15,67 & 2,20 \\
16 & Grobogan & 75 & 19,73 & 2,52 \\
\hline
\end{tabular}

dengan potensi hasil 2,14 ton/ha, dan G $511 \mathrm{H} /$ Anjasmoro-1-6 memiliki umur masak 75 hari, bobot 100 biji 17,08 g dengan potensi hasil 2,46 ton/ha (Tabel 3). Ketiga genotipe tersebut memiliki harapan untuk memenuhi preferensi pengguna kedelai saat ini di Indonesia. Ketiga genotipe tersebut dapat digunakan sebagai sumber gen untuk meningkatkan ketahanan varietas kedelai terhadap pengisap polong.

\section{SIMPULAN}

Genotipe G 511 H/Anjasmoro//Anjasmoro-2-8, G $511 \mathrm{H} /$ Anjasmoro-1-2, dan G $511 \mathrm{H} /$ Anjasmoro-1-6 menunjukkan tingkat serangan yang lebih rendah bila dibandingkan dengan genotipe lainnya dan terindikasi konsisten agak tahan pengisap polong kompleks berdasarkan intensitas serangan pada polong dan biji di lapangan. Karakter polong pada kedelai memiliki peran penting dalam mengendalikan kerusakan biji oleh hama pengisap polong. Oleh karena itu, strategi peningkatan ketahanan kedelai terhadap pengisap polong dapat dilakukan dengan memperbaiki karakter kulit polong melalui rekayasa genetika.

\section{SANWACANA}

Terima kasih kami sampaikan kepada Badan Penelitian dan Pengembangan Pertanian yang telah memberikan dana melalui DIPA untuk terlaksananya penelitian ini hingga selesai serta kepada Arifin yang telah membantu pelaksanaan penelitian di lapang hingga selesai.

\section{DAFTAR PUSTAKA}

Afifah L, Hidayat P, Buchori D, Marwoto, \& Rahardjo BT. 2015. Pengaruh perbedaan pengelolaan agroekosistem tanaman terhadap struktur komunitas serangga pada pertanaman kedelai di Ngale, Kabupaten Ngawi, Jawa Timur. J. HPT Tropika 15(1): 53-64.

Afzal M, Nazir Z, Bashir MH, \& Khan BS. 2009. Analysis of host plant resistance in some genotypes of maize against Chilo partellus (Swinhoe) (Pyralidae: Lepidoptera). Pak. J. Bot. 41(1): 421428.

Arifin M \& Tengkano W. 2010. Tingkat kerusakan ekonomi hama kepik punggung bergaris, Piezodorus hybneri pada kedelai. J. Penelitian Pertanian Tanaman Pangan 29(1): 42-49. 
Asadi. 2009. Identifikasi ketahanan sumber daya genetik kedelai terhadap hama pengisap polong. Buletin Plasma Nutfah 15(1): 27-31.

Bae SD, Kim HJ, Yoon YN, Park ST, Choi BR, \& Jung JK. 2009. Effects of mungbean cultivar, Jangannogdu, on nymphal development, adult longevity, and oviposition of soybean stink bug. Korean J. Appl. Entomol. 48(3): 311-318.

Bae SD, Kim HJ, \& Mainali BP. 2014. Infestation of Riptortus pedestris (Fabricius) decreases the nutritional quality and germination potential of soybean seeds. J. Asia-Pac. Entomol. 17(3): 477-481.

Bayu MSYI, Christanto, \& Tengkano W. 2011. Komposisi genus dan spesies pengisap polong kedelai pada pertanaman kedelai. Dalam: Widjono A, Hermanto, Nugrahaeni N, Rahmianna AA, Suharsono, Rozi F, Ginting E, Taufiq A, Harsono A, Prayogo Y, \& Yusnawan E (Eds.) Prosiding Seminar Hasil Penelitian Tanaman Aneka Kacang dan Umbi Tahun 2012. pp. 271-278. Tanggal 15 Juli 2012. Balai Penelitian Kacang dan Umbi. Malang.

Bayu MSYI \& Tengkano W. 2014. Evaluasi ketahanan galur-galur harapan kedelai toleran lahan masam dan kekeringan terhadap kepik coklat. Dalam: Prosiding Seminar Nasional 3 in 1, Hortikultura, Agronomi, dan Pemuliaan Tanaman.pp. 322-327. Tanggal 21 Agustus 2013. Fakultas Pertanian. Universitas Brawijaya. Malang.

Courtois EA, Paine CE, Blandinieres PA, Stien D, \& Bessiere JM, Hovel E, Baraloto C, \& Chave J. 2009. Diversity of the volatile organic compounds emitted by 55 species of tropical trees: a survey in French Guiana. J. Chem. Ecol. 35(11): 13491362.

Colazza S \& Wajnberg E. 2013. Chemical ecology of insect parasitoids: towards a new era. In: Wajnberg E \& Colazza S (Eds.). Chemical Ecology of Insect Parasitoids. ${ }^{\text {st }}$ Edition pp. 1-8. John Wiley \& Sons Ltd., Chichester, UK.

Cordeiro EMG, Correa AS, \& Guedes RNC. 2014. Insecticide mediated shift in ecological dominance between two competing species of grain beetles. PLoS One 9(6): e1009900.

Depieri RA \& Panizzi AR. 2011. Duration of feeding and superficial and in-depth damage to soybean seed by selected species of stink bugs (Heteroptera: Pentatomidae). Neotrop. Entomol. 40(2): 197-203.

Furstenberg-Hagg J, Zagrobelny M, \& Bak S. 2013. Plant defense against insect herbivores. Int. J. Mol. Sci. 14(5): 10242-10297.

Guedes RNC, Smagghe G, Stark JD, \& Desneux N. 2016. Pesticide-induced stress in arthropod pests for optimized integrated pest management programs. Annu. Rev. Entomol. 61: 43-62.

Haddi K, Mendonça LP, Dos Santos MF, Guedes RNC, \& Oliveira EE. 2015. Metabolic and behavioral mechanisms of indoxacarb resistance in Sitophilus zeamais (Coleoptera: Curculionidae). J. Econ. Entomol. 108(1): 362-369.

Hendrival, Latifah, \& Nisa A. 2013. Efikasi beberapa insektisida nabati untuk mengendalikan hama pengisap polong di pertanaman kedelai. J. Agrista 17(18): 18-27.

Krisnawati A, Bayu MSYI, \& Adie MM. 2016. Identification of soybean resistance to pod sucking bug (Riptortus linearis) by no-choice test. Biosaintifika 8(3): 407-413.

Leonard BR, Boquet DJ, Padgett B, Davis JA, Schneider R, Griffin JL, Valverde RA, \& Levy Jr RJ. 2011. Soybean green plant malady contributing factors and mitigation. Louisiana Agric. 54: 32-34.

Lourenção AL, Reco PC, Braga NR, do Valle GE, \& Pinheiro JB. 2010. Produtividade de genótipos de soja sob infestação da lagarta-da-soja e de percevejos. Neotropical Entomology. 39(2): 275281.

Mainali BP \& Lim UT. 2012. Annual pattern of occurrence of Riptortus pedestris (Hemiptera: Alydidae) and its egg parasitoids Ooencyrtus nezarae Ishii and Gryon japonicum (Ashmead) in Andong, Korea. Crop. Prot. 36: 37-42.

Mainali BP, Kim HJ, Yoon YN, Oh IS, \& Bae SD. 2014. Evaluation of different leguminous seeds as food sources for the bean bug Riptortus pedestris. J. Asia-Pac. Entomol. 17(2): 115-117.

McPherson RM, Buss GR, \& Roberts PM. 2007. Assessing stink bug resistance in soybean breeding lines containing genes from germplasm IAC-100. J. Econ. Entomol. 100(4): 1456-1463.

Michereff MFF, Laumann RA, Borges M, MichereffFilho M, Diniz IR, Neto ALF, \& Moreas MCB. 
2011. Volatiles mediating a plant-herbivore-natural enemy interaction in resistant and susceptible soybean cultivars. J. Chem. Ecol. 37(3): 273285.

Morando R, Baldin ELL, Cruz PL, Lourencao AL, \& Chiorato AF. 2015. Antixenosis of bean genotypes to Chrysodeixis includens (Lepidoptera: Noctuidae). Pesq. Agropec. Bras. 50(5): 450458.

Panizzi AR. 2013. History and contemporary perspectives of the integrated pest management of soybean in Brazil. Neotrop. Entomol. 42(2): 119-127.

Razaq M, Suhail A, Aslam M, Arif MJ, Saleem MA, \& Khan HA. 2013. Patterns of insecticides used on cotton before introduction of genetically modified cotton in Southern Punjab, Pakistan. Pakistan J. Zool. 45(2): 574-577.

Seo MJ, Kwon HR, Yoon KS, Kang MA, Park MW, Jo SH, Shin HS, Kim SH, Kang EJ, Yu YM, \& Youn YN. 2011. Seasonal occurrence, development, and preference of Riptortus pedestris on hairy vetch. Korean J. Appl. Entomol. 50(1): 47-53.

Smith CM \& Clement SL. 2012. Molecular bases of plant resistance to arthropods. Annu. Rev. Entomol. 57: 309-328.
Souza BHS, Junior ALB, Janini JC, Silva AGD, \& Rodrigues NEL. 2012. Feeding of Spodoptera eridania (Lepidoptera: Noctuidae) on soybean genotypes. Revista Colombiana de Entomologia 38(2): 215-223.

Suharsono \& Sulistyowati L. 2012. Expression of resistance of soybean to the pod sucking bug Riptortus linearis F. (Hemiptera: Coreidae). Agrivita 34(1): 55-59.

Timbo RV, Hermes-Lima M, Silva LP, Mehta A, Moraes MCB, \& Paula DP. 2014. Biochemical aspects of the soybean response to herbivory injury by the brown stink bug Euschistus heros (Hemiptera: Pentatomidae). PLoS One 9(10): e109735.

Veiga RFA, Rossetto CJ, Razera LF, Galo PB, \& Bortoleto M. 1999. Characterizing the morfolologic and agronomic soybean cultivar IAC-100. Agronomic Institute of Campinas. Bulletin Technic 175: 1-25.

War AR, Paulraj MG, Ahmad T, Buhroo AA, Hussain B, Ignacimuthu S, \& Sharma HC. 2012. Mechanisms of plant defense against insect herbivores. Plant Signal. Behav. 7(10): 13061320 . 